\title{
Meningkatkan Pemahaman Konsep Siswa Melalui Pendekatan Investigasi pada Materi Pesawat Sederhana Kelas VII di SMP Negeri 1 Gunung Purei
}

\author{
Enhancing Students' Conceptual Understanding Through Investigative \\ Approach in Simple Machines Material at Eighth Grade of SMP Negeri 1 \\ Gunung Purei
}

\author{
Rusniati $^{1^{*}}$, Suhartono ${ }^{2}$, Pendi Sinulingga ${ }^{3}$, Pri Ariadi Cahya DInata ${ }^{4}$ \\ ${ }^{1,2,3,4}$ Pendidikan Fisika, Fakultas Keguruan dan Ilmu Pendidikan, \\ Universitas Palangka Raya, Palangka Raya - Indonesia 73111 \\ *E-mail: rusniati14@gmail.com
}

\begin{abstract}
Abstrak
Pemahaman konsep merupakan kemampuan yang dimiliki siswa untuk menghubungkan konsep atau fakta sesuai dengan pengetahuan yang dimilikinya. Penelitian ini bertujuan untuk mengetahui partisipasi dan peningkatan pemahaman konsep siswa terhadap materi pesawat sederhana setelah mengikuti pembelajaran dengan menggunakan pendekatan investigasi. Penelitian ini menggunakan desain penelitian One-Group Pretest-Posttest Design. Populasi penelitian adalah seluruh kelas VIII semester 1 SMP Negeri 1 Gunung Purei tahun ajaran 2018/2019. Sampel penelitian sebanyak satu kelas diperoleh dengan menggunakan teknik random sampling, yaitu kelas VIII-A dengan jumlah siswa 24 orang. Pengambilan data menggunakan instrumen berupa: (1) lembar pengamatan partisipasi siswa dan (2) tes uraian pemahaman konsep dengan label konsep. Analisis data menggunakan (1) lembar observasi pengamatan dan (2) menggunakan rumus $\mathrm{N}$-Gain. Hasil penelitian diperoleh skor partisipasi siswa melakukan percobaan dan bertanya kepada guru sebesar 77 dan 86 dengan kategori baik, skor mengemukakan pendapat dan mengkomunikasikan hasil kerja kelompok sebesar 75 dan 72 dengan kategori cukup baik, serta skor merevisi hasil kerja kelompok sebesar 63 dengan kategori kurang. Peningkatan pemahaman siswa Label Konsep Tuas dan Katrol sebesar 36\% dengan skor $\mathrm{N}$-Gain 0,36 berada pada kategori sedang dan peningkatan pemahaman siswa Label Konsep Bidang Miring dan Roda Berporos sebesar $38 \%$ dengan skor $N$-Gain 0,38 berada pada kategori sedang. Dengan demikian, dapat disimpulkan bahwa penggunaan pendekatan investigasi dapat meningkatkan partisipasi siswa dan pemahaman konsep siswa.
\end{abstract}

Kata kunci: Pemahaman Konsep, Partisipasi Siswa, Pendekatan Investigasi

\begin{abstract}
Understanding the concept is the ability possessed by students to connect concepts or facts in accordance with the knowledge they have. This study aims to find out improvement of students' participation and conceptual understanding in simple machine material after following learning using an investigative approach. This study uses the One-Group Pretest-Posttest Design research design. The study population was all class VIII $1^{\text {st }}$ semester of Gunung Purei 1 Junior High School 2018/2019. One class of research sample was obtained using random sampling technique, namely class VIII-A
\end{abstract}


with 24 students. Data retrieval uses instruments in the form of: (1) student participation observation sheet and (2) test description of concept understanding with concept label. Data analysis used (1) observation observation sheet and (2) using N-Gain formula. The results obtained scores of student participation in conducting experiments at 77 with good categories, scores expressing opinions or ideas amounting to 75 with fairly good categories, scores asking questions to teachers amounting to 86 with good categories, scores communicating group work results of 72 with a fairly good category, and the score revising group work results by 63 with less categories. Increasing students' understanding of the Lever and Pulley Concept Label by $36 \%$ with the N-Gain score of 0.36 in the medium category and increasing student understanding Inclined Plane and Wheel and Axle Concept Labels were 38\% with the N-Gain score of 0.38 in the medium category. Thus, it can be concluded that the use of an investigative approach can increase student participation and understanding students' concepts

Keywords: Conceptual Understanding, Student Participation, Investigative Approach 


\section{PENDAHULUAN}

Proses pembelajaran IPA menekankan pada pemberian pengalaman langsung untuk mengembangkan kompetensi agar menjelajahi dan memahami alam sekitar secara ilmiah. Siswa hendaknya melakukan proses belajar melalui partisipasi secara aktif dengan konsep-konsep dan prinsipprinsip sehingga dapat menghasilkan pengetahuan yang bermakna (Dahar, 1996: 103).

Berdasarkan pengalaman peneliti saat melakukan kegiatan belajar mengajar (sebagai guru bantu) di kelas VIII SMP Negeri 1 Gunung Purei pada Januari 2018 (awal semester dua tahun ajaran 2017/2018), partisipasi siswa masih kurang. Siswa cenderung pasif selama pembelajaran, terlihat pada saat pembelajaran berlangsung masih ada beberapa siswa yang sibuk dengan kegiatannya sendiri misalnya bermain-main, berbicara diluar topik pelajaran bersama temannya, sering keluar masuk kelas dengan alasan yang beragam.

Partisipasi siswa yang kurang dalam pembelajaran mengakibatkan siswa menjadi kurang memahami pelajaran. Pernyataan tersebut diperkuat dengan hasil belajar kognitif siswa dari salah satu guru di SMP Negeri 1 Gunung Purei bahwa hasil belajar siswa masih di bawah nilai Kriteria Ketuntasan Minimal (KKM) pada sekolah tersebut yaitu sebesar 70. Nilai rata-rata ulangan harian semester ganjil tahun ajaran 2017/2018 pada mata pelajaran IPA materi Pesawat Sederhana yang disajikan pada Tabel 1 berikut

Tabel 1. Nilai Rata-rata Ulangan Harian Mata Pelajaran IPA Materi Pesawat Sederhana Semester Ganjil Tahun Ajaran 2017/2018

\begin{tabular}{|c|c|c|}
\hline Kelas & VIII A & VIII B \\
\hline Nilai rata-rata & 67 & 65 \\
\hline
\end{tabular}

Berdasarkan nilai rata-rata ulangan harian siswa pada Tabel 1 di atas, siswa belum mencapai nilai Kriteria Ketuntasan Minimal (KKM) yang ditetapkan di SMP tersebut yakni $\geq 70$. Hal tersebut membuat peneliti ingin melakukan upaya yang lebih maksimal lagi untuk tercapainya peningkatan kualitas pembelajaran yang sebelumnya belum berhasil dicapai oleh guru.

\section{BAHAN DAN METODE}

Populasi dalam penelitian ini adalah seluruh siswa kelas VIII semester 1 SMP Negeri 1 Gunung Purei tahun ajaran 2018/2019, yang terdiri dari 2 (dua) kelas. Sebaran populasi yaitu jumlah seluruh siswa pada setiap kelas. Sebaran populasi terdapat pada Tabel 2 berikut:

Tabel 2. Sebaran Populasi Penelitian

\begin{tabular}{|c|c|c|}
\hline No. & Kelas & Jumlah Siswa \\
\hline 1. & VIII-A & 24 \\
\hline 2. & VIII-B & 26 \\
\hline \multicolumn{2}{|c|}{ Jumlah siswa } & 50 \\
\hline
\end{tabular}

Sampel penelitian ini sebanyak 1 kelas. Pemilihan sampel dilakukan secara acak (random sampling) berdasarkan asumsi kelasnya homogen (Suharsimi, 2010: 174). Sampel yang terpilih adalah kelas VIII-A SMP Negeri 1 Gunung Purei dengan jumlah siswa 24.

Penelitian ini menggunakan 2 (dua) jenis instrumen dalam mengumpulkan data, yaitu: 
1. Lembar pengamatan partisipasi siswa Indikator partisipasi siswa yang dinilai/diamati adalah siswa melakukan percobaan, siswa mengemukakan pendapat atau ide dalam diskusi kelompok, siswa bertanya pada guru dalam kegiatan diskusi kelompok, siswa mengkomunikasikan hasil kerja kelompok, dan siswa merevisi hasil kerja kelompok. Setiap indikator partisipasi siswa diberi skor 1 sampai 3 , dengan keterangan yang terdapat pada lembar pengamatan partisipasi siswa.

2. Tes pemahaman konsep dalam bentuk tes uraian dengan bentuk LK (Label Konsep) sebanyak 16 soal dengan rincian 8 soal untuk label konsep Tuas dan Katrol dan 8 soal label konsep Bidang Miring dan Roda Berporos untuk mengukur pemahaman konsep.

Teknik Analisis Penilaian Partisipasi Siswa merupakan penilaian partisipasi siswa yang dilakukan pengamat untuk mengukur tingkat partisipasi dari siswa yang meliputi aspek siswa melakukan percobaan, siswa mengemukakan pendapat atau ide dalam diskusi kelompok, siswa bertanya pada guru dalam kegiatan diskusi kelompok, siswa mengkomunikasikan hasil kerja kelompok, dan siswa merevisi hasil kerja kelompok. Skala penilaian partisipasi siswa ditentukan dengan menggunakan persamaan 1 berikut (Sugiyono, 2013).

Skala penilaian $=\frac{\text { skor maksimum }- \text { skor minimum }}{\text { jumlah } \text { indikator }}$

Kriteria perolehan skor partisipasi siswa diukur menggunakan skala penilaian, yaitu: interval 53 sampai 64 diketegorikan kurang, 65 sampai 76 cukup baik, 77 sampai 88 baik dan 89 sampai 100 sangat baik 2 kurang (Sugiyono, 2013).

Teknik Analisis Data Peningkatan Pemahaman Konsep. (1) Memberikan skor pretest dan posttest. (2) Menghitung rata-rata skor pretest dan posttest dengan menggunakan persamaan 2 berikut (Abdurrahman, 2012: 34):

$$
\bar{S}=\frac{\sum S_{i}}{N}
$$

(3) Menghitung persentase rata-rata skor pretest dan posttest dengan persamaan 3 berikut (Henny, 2012: 61):

$\% \bar{S}=\frac{\bar{s}}{\text { skor ideal }} \times 100 \%$

(4) Menghitung skor $N$-Gain. $N$-Gain adalah perbandingan besar peningkatan yang diperoleh dengan besarnya peningkatan maksimum, secara matematis dinyatakan pada persamaan 4 berikut (Hake, 1998: 65):

$|\mathrm{g}|=\frac{\% \bar{S}_{\text {post }}-\% \bar{S}_{\text {pre }}}{100 \%-\% \bar{S}_{\text {pre }}}$

\section{HASIL}

Penelitian ini dilaksanakan mulai hari Rabu tanggal 10 September 2018 untuk RPP I (Label Konsep Tuas dan Katrol) dan Sabtu 15 September 2018 untuk RPP II (Label Konsep Bidang Miring dan Roda Berporos) di SMP Negeri 1 Gunung Purei. 
Tabel 3. Hasil Pengamatan Partisipasi Siswa

\begin{tabular}{|c|c|c|c|c|c|}
\hline \multirow[b]{2}{*}{ No. } & \multirow[b]{2}{*}{$\begin{array}{c}\text { Indikator Pengamatan } \\
\text { Partisipasi Siswa }\end{array}$} & \multicolumn{2}{|c|}{ Skor Perolehan } & \multirow[b]{2}{*}{$\begin{array}{l}\text { Rata-rata } \\
\text { Skor per } \\
\text { Indikator }\end{array}$} & \multirow[b]{2}{*}{ Kategori } \\
\hline & & $\begin{array}{c}\text { LK Tuas } \\
\text { dan Katrol }\end{array}$ & $\begin{array}{c}\text { LK Bidang } \\
\text { Miring dan } \\
\text { Roda } \\
\text { Berporos } \\
\end{array}$ & & \\
\hline 1. & Melakukanpercobaan & 62 & 92 & 77 & Baik \\
\hline 2. & $\begin{array}{l}\text { Mengemukakan pendapat atau } \\
\text { ide dalam diskusikelompok }\end{array}$ & 60 & 90 & 75 & $\begin{array}{l}\text { Cukup } \\
\text { Baik }\end{array}$ \\
\hline 3. & $\begin{array}{l}\text { Bertanya kepada guru dalam } \\
\text { kegiatan diskusi kelompok }\end{array}$ & 86 & 85 & 86 & Baik \\
\hline 4. & $\begin{array}{l}\text { Mengkomunikasikan hasilkerja } \\
\text { kelompok }\end{array}$ & 75 & 69 & 72 & $\begin{array}{l}\text { Cukup } \\
\text { Baik } \\
\end{array}$ \\
\hline 5. & Merevisi hasil kerja kelompok & 61 & 65 & 63 & Kurang \\
\hline \multicolumn{2}{|c|}{$\begin{array}{l}\text { Rata-rata Skor Partisipasi per Label } \\
\text { Konsep }\end{array}$} & 68,8 & 80,2 & 74,6 & \\
\hline \multicolumn{2}{|c|}{ Kategori } & Cukup Baik & Baik & $\begin{array}{l}\text { Cukup } \\
\text { Baik }\end{array}$ & \\
\hline
\end{tabular}

Data hasil pemahaman konsep tiap siswa disajikan pada Tabel 4.

Tabel 4. Pemahaman Konsep tiap Siswa

\begin{tabular}{|c|c|c|c|c|c|c|c|c|}
\hline \multirow{2}{*}{$\begin{array}{l}\text { Kode } \\
\text { Siswa }\end{array}$} & \multicolumn{2}{|c|}{ LK Tuas dan Katrol } & \multirow{2}{*}{$N$-Gain } & \multirow{2}{*}{$\begin{array}{c}\text { Ket. } \\
N \text {-Gain }\end{array}$} & \multicolumn{2}{|c|}{$\begin{array}{l}\text { LK Bidang Miring } \\
\text { dan Roda Berporos }\end{array}$} & \multirow[t]{2}{*}{ N-Gain } & \multirow{2}{*}{$\begin{array}{l}\text { Ket. } \\
\text { N-Gain }\end{array}$} \\
\hline & Pretest & Posttest & & & Pretest & Posttest & & \\
\hline S-1 & 14,81 & 81,48 & 0,78 & Tinggi & 10,71 & 82,14 & 0,80 & Tinggi \\
\hline S-2 & 14,81 & 77,78 & 0,74 & Tinggi & 7,14 & 78,57 & 0,77 & Tinggi \\
\hline $\mathrm{S}-3$ & 18,52 & 77,78 & 0,73 & Tinggi & 7,14 & 67,86 & 0,65 & Sedang \\
\hline S-4 & 14,81 & 62,96 & 0,57 & Sedang & 7,14 & 71,43 & 0,69 & Sedang \\
\hline S-5 & 14,81 & 59,26 & 0,52 & Sedang & 7,14 & 64,29 & 0,62 & Sedang \\
\hline S-6 & 14,81 & 59,26 & 0,52 & Sedang & 7,14 & 60,71 & 0,58 & Sedang \\
\hline S-7 & 18,52 & 59,26 & 0,50 & Sedang & 7,14 & 53,57 & 0,50 & Sedang \\
\hline S-8 & 18,52 & 55,56 & 0,45 & Sedang & 3,57 & 50,00 & 0,48 & Sedang \\
\hline S-9 & 14,81 & 40,74 & 0,30 & Sedang & 0,00 & 42,86 & 0,43 & Sedang \\
\hline S-10 & 11,11 & 40,74 & 0,33 & Sedang & 3,57 & 35,71 & 0,33 & Sedang \\
\hline S-11 & 3,70 & 40,74 & 0,38 & Sedang & 7,14 & 32,14 & 0,27 & Rendah \\
\hline S-12 & 7,41 & 37,04 & 0,32 & Sedang & 0,00 & 32,14 & 0,32 & Sedang \\
\hline S-13 & 3,70 & 33,33 & 0,31 & Sedang & 7,14 & 28,57 & 0,23 & Rendah \\
\hline S-14 & 7,41 & 33,33 & 0,28 & Rendah & 7,14 & 28,57 & 0,23 & Rendah \\
\hline S-15 & 14,81 & 33,33 & 0,22 & Rendah & 0,00 & 25,00 & 0,25 & Rendah \\
\hline S-16 & 11,11 & 29,63 & 0,21 & Rendah & 7,14 & 25,00 & 0,19 & Rendah \\
\hline S-17 & 11,11 & 25,93 & 0,17 & Rendah & 3,57 & 25,00 & 0,22 & Rendah \\
\hline S-18 & 11,11 & 25,93 & 0,17 & Rendah & 0,00 & 17,86 & 0,18 & Rendah \\
\hline S-19 & 7,41 & 22,22 & 0,16 & Rendah & 3,57 & 17,86 & 0,15 & Rendah \\
\hline S-20 & 0,00 & 22,22 & 0,22 & Rendah & 0,00 & 14,29 & 0,14 & Rendah \\
\hline S-21 & 7,41 & 29,63 & 0,24 & Rendah & 7,14 & 46,43 & 0,42 & Sedang \\
\hline S-22 & 11,11 & 33,33 & 0,25 & Rendah & 3,57 & 32,14 & 0,30 & Rendah \\
\hline S-23 & 0,00 & 25,93 & 0,26 & Rendah & 0,00 & 28,57 & 0,29 & Rendah \\
\hline S-24 & 11,11 & 33,33 & 0,25 & Rendah & 3,57 & 28,57 & 0,26 & Rendah \\
\hline
\end{tabular}

Berdasarkan Tabel 4, hasil peningkatan pemahaman konsep untuk label konsep Tuas dan Katrol diperoleh 3 orang siswa kategori tinggi, 10 orang siswa kategori sedang, dan 11 orang siswa kategori rendah. Hasil peningkatan pemahaman konsep untuk label konsep Bidang Miring dan Roda Berporos diperoleh 2 orang siswa kategori tinggi, 10 orang siswa kategori sedang, dan 12 orang siswa kategori rendah

Data peningkatan pemahaman konsep untuk masing-masing Label Konsep disajikan pada Tabel 5 berikut ini. 
Tabel 5. Data Peningkatan Pemahaman Konsep untuk setiap Label Konsep

\begin{tabular}{|l|c|c|c|c|}
\hline \multicolumn{1}{|c|}{ Label Konsep } & Pretest & Posttest & N-Gain & Keterangan $\boldsymbol{N}$-Gain \\
\hline Tuas dan Katrol & 10,96 & 43,36 & 0,36 & Sedang \\
\hline $\begin{array}{l}\text { Bidang Miring dan Roda } \\
\text { Berporos }\end{array}$ & 4,61 & 41,22 & 0,38 & Sedang \\
\hline Rata-rata Skor Label Konsep & 7,79 & 42,29 & 0,37 & Sedang \\
\hline
\end{tabular}

\section{PEMBAHASAN}

Skor partisipasi siswa untuk setiap indikator pengamatan disajikan pada Gambar 1 berikut.

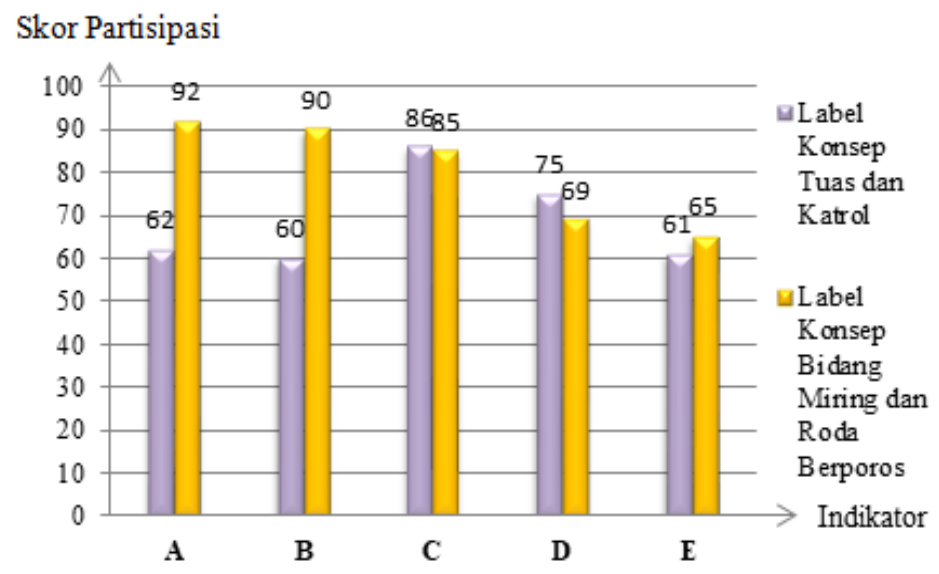

Gambar 1. Gambar Skor Partisipasi Siswa tiap Indikator Pengamatan

\section{a. Partisipasi Siswa Melakukan Percobaan}

Faktor penyebab rendahnya nilai partisipasi siswa pada pertemuan pertama: (1) banyak siswa tidak memahami instruksi pada LKS, bahkan ada beberapa kelompok yang tidak membaca langkah-langkah percobaan di LKS, (2) masih ada sebagian siswa yang tidak mau bekerja kelompok. Faktor penyebab tingginya partisipasi siswa pada pertemuan kedua dalam melakukan percobaan (1) anggota kelompok berjumlah 4-5 orang, sehingga setiap siswa mendapat peran dalam melakukan percobaan sehingga kerja kelompok menjadi lebih maksimal (2) lebih banyak siswa yang turut berpartisipasi melakukan percobaan secara dominan, dan juga guru sudah memberikan arahan dengan lebih jelas sehingga lebih banyak siswa yang memahami langkah-langkah percobaan.

b. Partisipasi Siswa Mengemukakan Pendapat atau Ide dalam Diskusi Kelompok

Faktor penyebab rendahnya nilai mengemukakan pendapat atau ide dalam diskusi kelompok pada pertemuan pertama (1) kurangnya kerja sama siswa dalam diskusi kelompok, (2) siswa masih kesulitan dalam mengkonversi satuan dan juga siswa kesulitan dalam mengoperasikan bilangan desimal, sehingga jawaban akhir siswa banyak yang salah. Faktor penyebab meningkatnya skor partisipasi siswa dalam mengemukakan pendapat atau ide dalam diskusi kelompok pada pertemuan kedua dikarenakan siswa sudah mulai terlatih pertanyaan yang terdapat pada LKS menuntut semua anggota kelompok untuk turut serta memberikan jawaban atau bertukar pikiran dengan anggota kelompoknya masing-masing. Hal ini tidak lepas juga dari kelebihan pendekatan investigasi yang membuat proses belajar siswa berlangsung secara bebas, cenderung terbuka, tidak terstruktur secara ketat oleh guru. Siswa diberikan kesempatan seluas-luasnya untuk belajar 
lebih aktif dan lebih bermakna menggunakan kemampuannya sendiri (Setiawan, 2006: 10). Sehingga rata-rata partisipasi siswa dalam mengemukakan pendapat atau ide dalam diskusi kelompok cukup baik.

c. Partisipasi Siswa Bertanya kepada Guru dalam Diskusi Kelompok

Rata-rata skor partisipasi siswa bertanya kepada guru dalam diskusi kelompok lebih besar dari pada rata-rata nilai aspek partisipasi yang lainnya. Hal ini disebabkam karena dalam berdiskusi, siswa selalu menanyakan apakah perkerjaan yang mereka lakukan sudah benar atau masih salah.

\section{d. Partisipasi Siswa Mengkomunikasikan Hasil Kerja Kelompok}

Faktor penyebab tidak semua siswa bersedia maju ke depan kelas untuk mengkomunikasikan hasil kerja kelompoknya. Kalaupun ada semua anggota kelompok yang maju namun hanya beberapa orang saja yang menjelaskan hasil percobaannya, anggota yang lain hanya ikut berdiri saja di depan kelas. Hal ini disebabkan pembagian tugas dalam kelompok tidak terstruktur dengan baik, dan juga disebabkan rasa malu untuk menjelaskan di depan kelas.

\section{e. Partisipasi Siswa Merevisi Hasil Kerja Kelompok}

Perolehan skor partisipasi siswa cukup rendah dibandingkan dengan perolehan skor partisipasi pada indikator pengamatan yang lainnya, hal tersebut dikarenakan sebagian besar siswa malas untuk menuliskan klarifikasi/penguatan konsep yang disampaikan guru, kebanyakan siswa hanya diam saja mendengarkan apa yang disampaikan guru. Faktor lain disebabkan karena sebagian besar siswa mengaku kelelahan sehingga siswa hanya mendengarkan saja tanpa menulis di buku catatannya.

Berdasarkan uraian di atas menunjukkan bahwa penggunaan pendekatan investigasi meningkatkan partisipasi siswa dalam pembelajaran dapat dilihat dari kemampuan keberanian mengeluarkan ide atau pendapat serta keberanian untuk bertanya kepada guru.

Hasil analisis $N$-Gain tiap siswa untuk label konsep Tuas dan Katrol dapat dilihat pada Gambar 2 berikut.

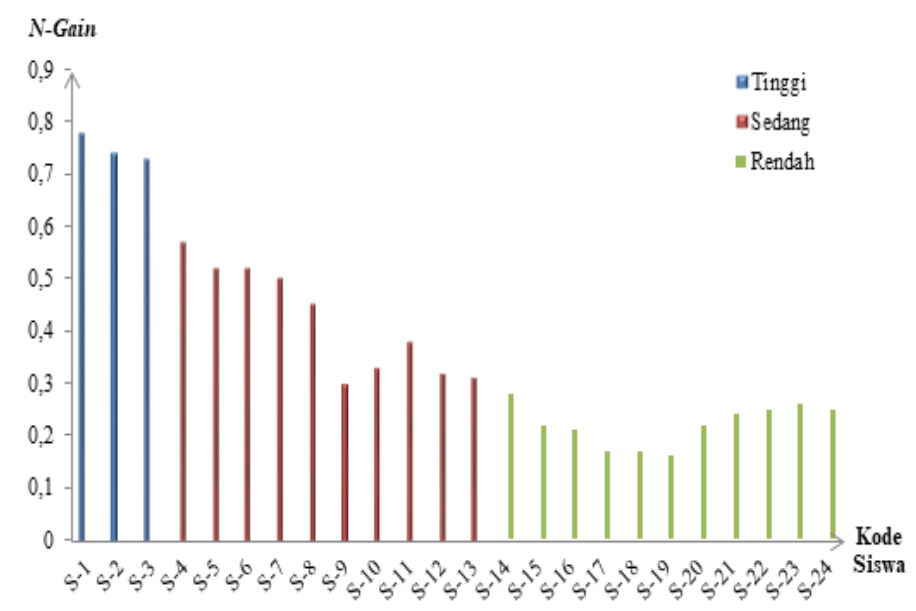

Gambar 2. Gambar N-Gain Tiap Siswa Label Konsep Tuas dan Katrol

Gambar 2 menunjukkan bahwa dari 24 siswa yang mengikuti pembelajaran dengan pendekatan investigasi terdapat 3 orang siswa dengan kategori $N$ Gain tinggi, 10 orang siswa dengan kategori $N$-Gain sedang, dan 11 
dengan kategori $\mathrm{N}$-Gain rendah. Faktor yang menyebabkan 3 orang siswa dengan kategori $\mathrm{N}$-Gain tinggi dan 10 orang siswa dengan kategori $\mathrm{N}$-Gain sedang dikarenakan siswa yang kategori $N$-Gain tinggi dan sedang terlihat aktif dalam kegiatan percobaan yang dilakukan dan siswa mau menjawab ketika guru bertanya dan selama percobaan berlangsung siswa ambil bagian dan tidak banyak bertanya dalam menyelesaikan langkahlangkah pada LKS.

Faktor yang menyebabkan 11 siswa dengan kategori $\mathrm{N}$-Gain rendah setelah diterapkan pembelajaran dengan pendekatan investigasi adalah:

1) Siswa yang tidak tuntas jika dilihat pada saat kegiatan percobaan masih kurang aktif dalam diskusi kelompok maupun dalam kegiatan pembelajaran. Selama kegiatan percobaan dilakukan siswa lebih banyak melihat temannya bekerja dibandingkan ambil bagian dalam kegiatan. Siswa kurang bekerja sama dalam menyelesaikan langkah LKS yang ada. Sedangkan dalam pelaksanaannya, semua kinerja anggota kelompok sangat diperlukan agar terciptanya kerja sama yang kompak untuk mendapatkan keberhasilan kelompok itu sendiri. Hal tersebut sesuai dengan pendapat Roger dan David Jonhson dalam Rusman (2014: 121) yang menyatakan bahwa keberhasilan dalam penyelesaian tugas tergantung pada usaha yang dilakukan oleh kelompok dan keberhasilan kerja kelompok ditentukan oleh kinerja masing-masing anggota kelompok, serta setiap anggota kelompok mempunyai tugas dan tanggung jawab yang harus dikerjakan dalam kelompok. Hal tersebut yang menyebabkan kurang maksimalnya hasil belajar yang diperoleh siswa.

2) Guru mengalami kesulitan dalam mengelola kelas pada saat pembelajaran. Kelas yang ribut menjadikan siswa kurang fokus dan tidak dapat memperhatikan penjelasan guru dengan baik, Selain itu, selama pembelajaran guru kurang memberikan motivasi yang berkaitan langsung dengan kehidupan sehari-hari sehingga selain kurang menarik bagi siswa, siswa juga kurang paham pada materi yang disampaikan. Hal ini sesuai dengan pendapat Wahab Jufri (2013: 143) yang menyatakan bahwa pada proses pembelajaran, motivasi merupakan salah satu aspek dinamis yang sangat penting dan sering terjadi siswa yang kurang berprestasi bukan disebabkan oleh kemampuannya yang kurang, akan tetapi dikarenakan tidak adanya motivasi untukbelajar sehingga peserta didik tidak berusaha untuk mengerahkan segala kemampuanya.

3) Persiapan guru dalam kegiatan belajar mengajar masih kurang, guru juga mengalami kesulitan pada saat pembagian kelompok siswa dikarenakan siswa tidak ingin kelompok yang dipilihkan guru, siswa hanya ingin sekelompok dengan teman akrab siswa saja.

4) Pada saat pemberian contoh-contoh soal, siswa masih mengalami kesulitan dalam soal hitungan. Terlihat setelah guru memberikan soal, guru berkeliling untuk melihat siswa mengerjakan soal tetapi siswa masih belum mengerjakan dan menunggu jawaban dari guru atau dari teman siswa yang mengerjakan soal di depan kelas.

Hasil analisis $N$-Gain tiap siswa untuk label konsep Bidang Miring dan Roda Berporos dapat dilihat pada Gambar 3 berikut. 


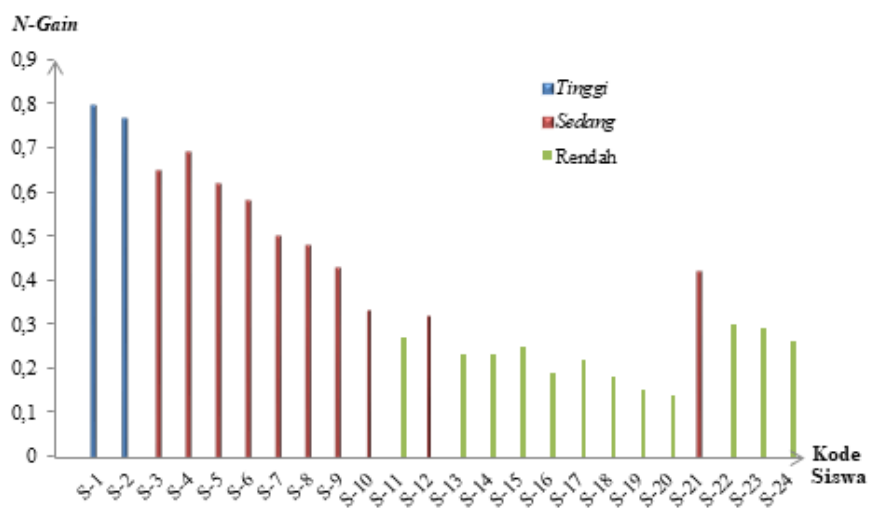

Gambar 3. Gambar N-Gain Tiap Siswa Label Bidang Miring dan Roda Berporos

Gambar 3 di atas menunjukkan bahwa dari 24 siswa yang mengikuti pembelajaran dengan pendekatan investigasi terdapat 2 orang siswa dengan kategori $\mathrm{N}$-Gain tinggi, 10 orang siswa dengan kategori $\mathrm{N}$-Gain sedang, dan 12 dengan kategori $N$-Gain rendah. Faktor yang menyebabkan 2 orang siswa dengan kategori $N$-Gain tinggi dan 10 orang siswa dengan kategori $N$-Gain sedang yaitu sebagai berikut:

1) Kategori $\mathrm{N}$-Gain tinggi, siswa dengan kemampuan akademik yang paling bagus di kelas.

2) Pada saat kegiatan percobaan, siswa yang tuntas terlihat aktif dalam kegiatan percobaan yang dilakukan dan siswa mau menjawab ketika guru bertanya dan selama percobaan berlangsung siswa ambil bagian dan tidak banyak bertanya dalam menyelesaikan langkah-langkah pada LKS.

3) Partisipasi siswa juga dapat mempengaruhi

Faktor yang menyebabkan 12 siswa dengan kategori $\mathrm{N}$-Gain rendah setelah diterapkan pembelajaran dengan pendekatan investigasi adalah:

1) Siswa yang tidak tuntas jika dilihat pada saat kegiatan percobaan masih kurang aktif dalam diskusi kelompok maupun dalam kegiatan pembelajaran. Selama kegiatan percobaan dilakukan siswa lebih banyak melihat temannya bekerja dibandingkan ambil bagian dalam kegiatan. Jika dilihat berdasarkan materi, terlihat banyak yang tidak tuntas pada materi gelombang. Meskipun pada kegiatan pembelajaran telah dilakukan kegiatan percobaan pada materi gelombang tetapi siswa masih belum paham terhadap materi. Selama percobaan pada materi gelombang, siswa masih bertanya kembali pada guru meskipun sebelumnya sudah diarahkan guru. Siswa kurang bekerja sama dalam menyelesaikan langkah LKS yang ada. Sedangkan dalam pelaksanaannya, semua kinerja anggota kelompok sangat diperlukan agar terciptanya kerja sama yang kompak untuk mendapatkan keberhasilan kelompok itu sendiri. Hal tersebut sesuai dengan pendapat Roger dan David Jonhson dalam Rusman (2014: 121) yang menyatakan bahwa keberhasilan dalam penyelesaian tugas tergantung pada usaha yang dilakukan oleh kelompok dan keberhasilan kerja kelompok ditentukan oleh kinerja masing-masing anggota kelompok, serta setiap anggota kelompok mempunyai tugas dan tanggung jawab yang harus dikerjakan dalam kelompok. Hal tersebut yang menyebabkan kurang maksimalnya hasil belajar yang diperoleh siswa.

2) Pemberian evaluasi yang harusnya dikerjakan di ruangan untuk mengetahui kemampuan siswa tetapi dikarenakan waktu yang tidak 
cukup sehingga harus dikerjakan di rumah. Terlihat dari hasil evaluasi yang dikerjakan, masih belum mendapatkan hasil yang memuaskan. Selain itu, masih terdapat siswa yang menyontek di kelas pada saat soal evaluasi akan dikumpulkan dikarenakan siswa tersebut belum mengerjakan di rumah. Hal ini terlihat jelas jika siswa tersebut tidak bersungguh-sungguh belajar dalam mengerjakan soal evaluasi yang diberikan.Hal ini sesuai dengan pendapat yang dikatakan Syaiful Bahri (2005: 264) yang mengatakan bahwa faktor penyebab siswa mendapatkan hasil belajar yang rendah yakni lamban dalam melakukan tugas-tugas kegiatan belajarnya, melakukan perilaku yang berkelainan seperti: membolos/tidak hadir, tidak mengerjakan tugas di dalam atau di luar kelas dan acuh tak acuh terhadap guru saat proses pembelajaran.

3) Kehadiran siswa pada saat pembelajaran juga mempengaruhi hasil belajar siswa yang tidak tuntas, dikarenakan siswa tersebut tidak mendapatkan penjelasan materi yang disampaikan guru.

4) Guru mengalami kesulitan dalam mengelola kelas pada saat pembelajaran. Kelas yang ribut menjadikan siswa kurang fokus dan tidak dapat memperhatikan penjelasan guru dengan baik, Selain itu, selama pembelajaran guru kurang memberikan motivasi yang berkaitan langsung dengan kehidupan sehari-hari sehingga selain kurang menarik bagi siswa, siswa juga kurang paham pada materi yang disampaikan. Hal ini sesuai dengan pendapat Wahab Jufri (2013: 143) yang menyatakan bahwa pada proses pembelajaran, motivasi merupakan salah satu aspek dinamis yang sangat penting dan sering terjadi siswa yang kurang berprestasi bukan disebabkan oleh kemampuannya yang kurang, akan tetapi dikarenakan tidak adanya motivasi untukbelajar sehingga peserta didik tidak berusaha untuk mengerahkan segala kemampuanya.

5) Persiapan guru dalam kegiatan belajar mengajar masih kurang, guru juga mengalami kesulitan pada saat pembagian kelompok siswa dikarenakan siswa tidak ingin kelompok yang dipilihkan guru, siswa hanya ingin sekelompok dengan teman akrab siswa saja.

6) Pada saat pemberian contoh-contoh soal, siswa masih mengalami kesulitan dalam soal hitungan. Terlihat setelah guru memberikan soal, guru berkeliling untuk melihat siswa mengerjakan soal tetapi siswa masih belum mengerjakan dan menunggu jawaban dari guru atau dari teman siswa yang mengerjakan soal di depan kelas.

Hasil analisis data pretest dan posttest untuk setiap label konsep dapat dilihat pada Gambar 4 berikut.

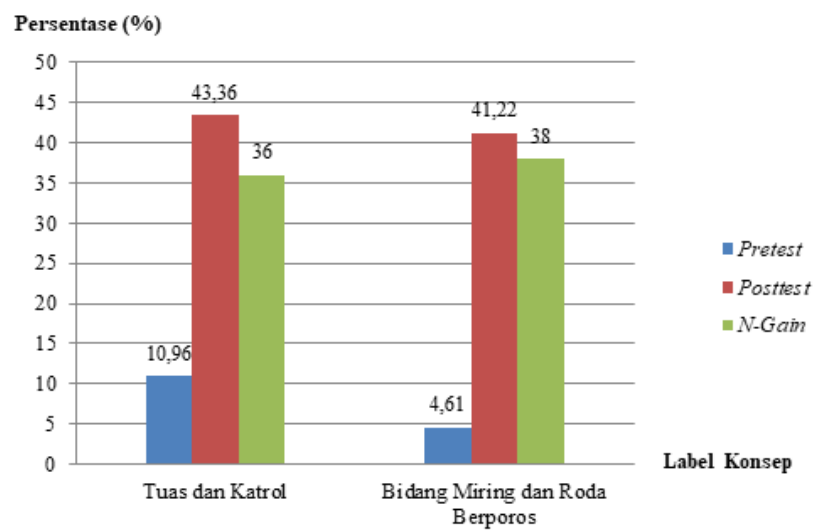

Gambar 4. Peningkatan Pemahaman Konsep Tiap Label Konsep 
Berdasarkan data pada Gambar 4, pada pertemuan pertama nilai pretest sebesar 10,96 dan posttest sebesar 43,36. Pada pertemuan pertama terjadi peningkatan pemahaman konsep sebesar 36\% dengan kategori sedang, hasil pretest dan posttest ini sama-sama masih belum mencapai nilai Kriteria Ketuntasan Minimum (KKM) yang ditetapkan yakni $\geq 70$ atau dikatakan tidak tuntas. Tidak tuntasnya pretest disebabkan karena pemahaman konsep yang keliru. Hal ini karena materi pada soal pretest memang belum diajarkan sebelumnya kepada siswa. Menyebabkan siswa cenderung menuliskan jawaban asal-asalan. Ketika guru bertanya mengapa menuliskan jawaban asal-asalan, siswa menjawab karena materi pada soal belum pernah mereka terima sebelumnya. Tidak tuntasnya nilai posttest ini disebabkan karena beberapa faktor sebagai berikut:

1) Siswa merasa kelelahan karena posttest ini dilakukan pada hari yang sama setelah selesai pembelajaran,

2) Siswa terfokus mengerjakan LKS sehingga mengabaikan adanya posttest di akhir pembelajaran. Peningkatan pemahaman konsep pada pertemuan pertama ini lebih rendah jika dibandingkan dengan peningkatan pemahaman konsep pada pertemuan kedua. Hal ini berkaitan dengan rendahnya nilai partisipasi siswa pada pertemuan pertama yaitu pada aspek melakukan percobaan dengan nilai 62, mengemukakan pendapat atau ide dalam diskusi kelompok dengan nilai 60 dan merevisi hasil kerja kelompok dengan nilai 61, ketiga aspek partisipasi ini dalam kategori kurang.

Pertemuan kedua nilai pretest sebesar 4,61 dan posttest sebesar 41,22. Pada pertemuan kedua terjadi peningkatan pemahaman konsep sebesar $38 \%$ dengan kategori sedang, hasil pretest dan posttest ini sama-sama masih belum mencapai nilai Kriteria Ketuntasan Minimum (KKM) yang ditetapkan yakni $\geq 70$ atau dikatakan tidak tuntas. Tidak tuntasnya pretest disebabkan karena pemahaman konsep yang keliru. Hal ini karena materi pada soal pretest memang belum diajarkan sebelumnya kepada siswa. Hal ini menyebabkan siswa cenderung menuliskan jawaban asal-asalan. Ketika guru bertanya mengapa menuliskan jawaban asal-asalan, siswa menjawab karena materi pada soal belum pernah mereka terima sebelumnya. Tidak tuntasnya nilai posttest ini disebabkan karena beberapa faktor sebagai berikut: (1) siswa merasa kelelahan karena posttest ini dilakukan pada hari yang sama setelah selesai pembelajaran (2) siswa terfokus mengerjakan LKS sehingga mengabaikan adanya posttest di akhir pembelajaran. Peningkatan pemahaman konsep pada pertemuan kedua ini lebih tinggi jika dibandingkan dengan peningkatan pemahaman konsep pada pertemuan pertama. Hal ini berkaitan dengan tingginya nilai partisipasi siswa pada pertemuan kedua.

Peningkatan pemahaman konsep yang dicapai siswa pada setiap label konsep ini tidak terlepas dari pendekatan pembelajaran yang diterapkan oleh guru, guru memfasilitasi siswa untuk melaksanakan pembelajaran yang bermakna. Penerapan pendekatan investigasi menuntun siswa untuk memahami konsep materi pelajaran dengan baik dan meminimalisir kesalahan konsep yang sebelumnya tertanam di benak siswa. Siswa diberi kesempatan untuk berpikir mandiri dalam memahami suatu permasalahan, kemudian berpikir untuk mencari cara penyelesaian masalah tentang konsep yang sedang dipelajari tersebut sehingga siswa mampu mengkonstruksikan kemampuannya dalam setiap aspek kemampuan pemahaman konsep. Meningkatnya nilai $N$-Gain dari 0,36 pada pertemuan pertama menjadi 0,38 pada pertemuan kedua ini tidak lepas dari 
meningkatnya nilai rata-rata partisipasi siswa, dari rata-rata 68,8 pada pertemuan pertama menjadi rata-rata 80,2 pada pertemuan kedua artinya semakin tinggi nilai partisipasi siswa maka semakin bagus pula pemahaman konsep siswa.

Peningkatan pemahaman konsep siswa pada label konsep Tuas dan Katrol dan label konsep Bidang Miring dan Roda Berporos telah memperlihatkan bahwa dengan menerapkan pendekatan investigasi dapat meningkatkan pemahaman konsep siswa dengan cukup baik. Hal ini sejalan dengan hasil penelitian dari Aris Kurniawan (2013) bahwa pembelajaran dengan pendekatan investigasi meningkatkan pemahaman konsep siswa dan partisipasi siswa baik. Pemahaman awal siswa yang masih keliru tentang suatu konsep Pesawat Sederhana dapat siswa temukan sendiri kebenarannya dalam pelaksanaan kegiatan investigasi, sehingga setelah mengikuti pembelajaran tersebut siswa tidak lagi keliru dalam memahami konsep yang telah siswa pelajari di sekolah bersama guru dan temantemannya.

Peningkatan skor $N$-Gain pemahaman konsep siswa pada pertemuan kedua terjadi dikarenakan guru telah melakukan perbaikan dari pembelajaran pada pertemuan pertama. Pada pertemuan kedua, guru mengajar dengan persiapan yang lebih maksimal agar pelajaran yang disampaikan lebih mudah dipahami siswa, materi yang diajarkan lebih terstruktur dan pengelolaan pembelajaran di kelas lebih diperhatikan. Beberapa hal tersebut dilakukan guru sebagai upaya peningkatkan pemahaman konsep siswa menjadi lebih maksimal.

Hal tersebut dapat terjadi karena pendekatan pembelajaran yang diterapkan oleh guru menekankan pada peran aktif siswa dalam membangun pemahamannya terhadap konsep materi yang dipelajari melalui kegiatan investigasi, yang sangat membantu siswa dalam berpikir mandiri untuk memahami dan menyelesaikan suatu permasalahan konsep. Hal ini sesuai dengan pendapat Krismanto (2003: 7) menyatakan bahwa investigasi atau penyelidikan merupakan kegiatan pembelajaran yang memberikan kesempatan kepada siswa untuk meningkatkan pemahaman siswa melalui berbagai kegiatan pengembangan yang dilalui siswa selama pembelajaran.

Hasil dalam penelitian ini didukung oleh hasil penelitian Nurul Ayu Fitriyanti (2014) bahwa dengan menerapkan pendekatan investigasi dapat meningkatkan pemahaman konsep siswa. Hasil penelitian ini juga mendukung temuan Devi Rizky (2013) bahwa pendekatan investigasi berpengaruh terhadap pemahaman konsep siswa. Selain itu, hasil penelitian ini juga mendukung temuan Aris Kurniawan (2013) bahwa bahwa pembelajaran dengan pendekatan investigasi meningkatkan pemahaman konsep siswa dan pastisipasi siswa baik. Berdasarkan deskripsi data yang telah dipaparkan, dapat disimpulkan bahwa pembelajaran dengan menggunakan pendekatan investigasi dapat meningkatkan pemahaman konsep siswa.

Gambaran partisipasi siswa dan peningkatan pemahaman konsep dalam penelitian ini disajikan dalam Gambar 5 berikut ini. 


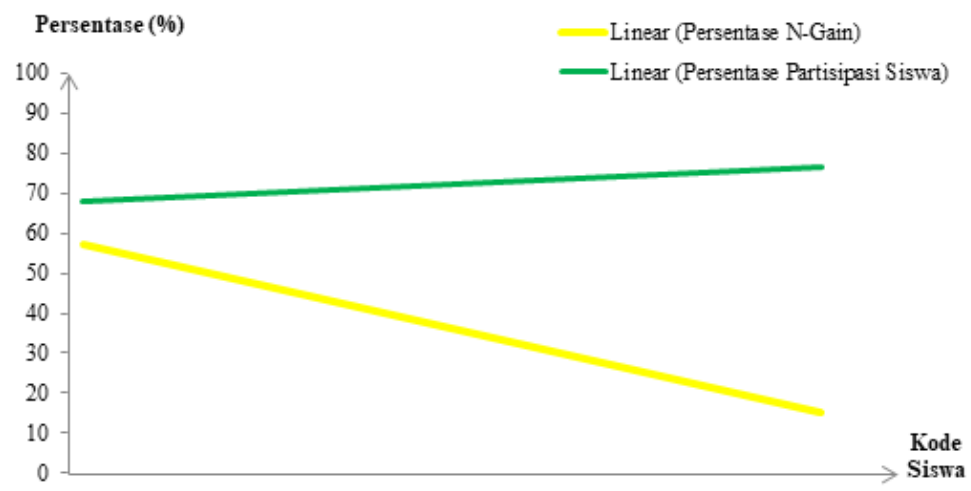

Gambar 5. Linieritas Partisipasi Siswa dan Peningkatan Pemahaman Konsep Siswa

Berdasarkan Gambar 5, terlihat bahwa garis linieritas antara partisipasi siswa dan peningkatan pemahaman konsep tidak linier. Dengan demikian jika seorang siswa mempunyai partisipasi yang baik dalam pembelajaran, maka pemahaman konsepnya belum tentu baik pula.

Hal tersebut terjadi karena partisipasi siswa bukanlah satu-satunya faktor yang berhubungan dengan pemahaman konsep siswa. Pemahaman bukan hanya sekedar mengingat fakta, akan tetapi berhubungan dengan kemampuan menjelaskan, menerangkan, menafsirkan atau kemampuan menangkap makna atau arti suatu konsep (Sanjaya, 2008: 126).

\section{SIMPULAN}

Berdasarkan data dan analisis hasil penelitian yang telah dilakukan mengenai penerapan pendekatan investigasi untuk meningkatkan pemahaman konsep siswa pada materi Pesawat Sederhana, dapat disimpulkan bahwa.

1. Skor partisipasi siswa melakukan percobaan dan skor bertanya kepada guru dalam kegiatan diskusi kelompok sebesar 77 dan 86 dengan kategori baik, skor mengemukakan pendapat atau ide dalam diskusi kelompok dan skor mengkomunikasikan hasil kerja kelompok sebesar 75 dan 72 dengan kategori cukup baik, serta skor merevisi hasil kerja kelompok sebesar 63 dengan kategori kurang.

2. Peningkatan pemahaman Label Konsep Tuas dan Katrol sebesar $36 \%$ dengan skor $\mathrm{N}$-Gain sebesar 0,36 berada pada kategori sedang, dan peningkatan pemahaman Label Konsep Bidang Miring dan Roda Berporos sebesar $38 \%$ dengan skor $N$-Gain sebesar 0,38 berada pada kategori sedang.

\section{REFERENSI}

Abdurrahman, D. 2012. Profil Tingkat Penalaran dan Peningkatan Penguasaan Konsep Siswa SMA dalam Pembelajaran Fisika Berbasis Rangking Task Exercise Peer Instruction. Skripsi Sarjana, tidak diterbitkan, UPI Bandung.

Bahri, S. 2005. Guru dan Anak Didik Dalam Interaksi Edukatif. Jakarta: Rineka Cipta.

Dahar, R. W. 1996. Teori-Teori Belajar. Jakarta: Erlangga

Fitriyanti, N. A. 2014. Meningkatkan Pemahaman Konsep Siswa melalui Pendekatan Investigasi pada Materi Getaran dan Gelombang Kelas VIII di MTs Negeri 2 Palangka Raya Tahun Ajaran 2013/2014. Skripsi Sarjana, tidak diterbitkan, Universitas Palangka Raya.

Hake, R. R. 1998. Interactive Engagement Versus Traditional Methods: A Six-ThousandStudent Survey Of Mechanics Test Data For Introductory Physics Courses. Department of Physics, Indiana University: American Association of Physics Teachers. 
Henny. 2012. Penerapan Pembelajaran Generatif dengan Strategi Problem Solving untuk Meningkatkan Pemahaman Konsep Siswa SMA pada Materi Fluida Statis. Skripsi Sarjana, tidak diterbitkan, UPI Bandung.

Krismanto, Al. 2003. Beberapa Teknik Model, dan Strategi Dalam Pembelajaran Matematika. Yogyakarta: PPPG Matematika Yogyakarta.

Kurniawan, A. 2013. Pembelajaran Fisika Menggunakan Pendekatan Konseptual Interaktif dengan Seting Investigasi Kelompok pada Materi Pokok Fluida Statis di Kelas XI IPA SMA Negeri 1 Palangkaraya Tahun Ajaran 2012/2013. Skripsi Sarjana, tidak diterbitkan, Universitas Palangka Raya.

Rizky, D. 2012. Pengaruh Pendekatan Investigasi terhadap Pemahaman Konsep pada Topik Bentuk Pangkat Siswa SMA Negeri 1 Pamotan Rembang. Jurnal Pendidikan Matematika S-1 , VI Volume II November-Desember 2013.

Rusman. 2014. Model-model Pembelajaran (Mengembangkan Profesionalisme Guru). Jakarta: Raja Grafindo Persada.

Sanjaya, W. 2011. Penelitian Tindakan Kelas. Jakarta: Kencana Prenada.

Setiawan. 2006. Model Pembelajaran Matematika dengan Pendekatan Investigasi. Yogyakarta: Dirjen Peningkatan Mutu Pendidik dan Tenaga Kependidikan Pusat Pengembangan dan Penataran Guru Matematika.

Sugiyono. 2013. Statistika untuk Penelitian. Bandung: Alfabeta.

Suharsimi. 2010. Prosedur Penelitian Suatu Pendekatan Praktik. Jakarta: Rineka Cipta.

Wahab, J. 2013. Belajar dan Pembelajaran SAINS. Bandung: Pustaka Reka Cipta. 